\title{
Performance of Irish Potato Varieties in an Oxisol in Northwestern Puerto Rico ${ }^{1,2}$
}

\author{
J. Badillo-Feliciano, M. A. Lugo-López, and S. Valle Lamboy ${ }^{3}$
}

\begin{abstract}
An experiment was conducted in an Oxisol (Tropeptic Haplorthox) in northwestern Puerto Rico to evaluate the potential for Irish potato production in this kind of soil at low elevations. Eleven varieties were tested in a partially balanced incomplete block design with 4 replications. The crop was planted in December 1974 and harvested after 109 days. Marketable yields ranged from 14.0 to 22.4 t/ha. Varieties Hudson, Red Lasoda, Red Pontiac and Chieftain yielded over $20 \mathrm{t} / \mathrm{ha}$ of marketable Irish potatoes. Sebago was the lowest yielder. Percentage of marketable yields ranged from 90 to 97 . Total yields followed the same trend as marketable yields. Hudson outyielded all varieties except Red Lasoda in terms of U.S. No. 1 tubers. There was an apparent negative relationship between disease rating and total yield. It is inferred that Irish potato production can be a profitable enterprise under local conditions if good management practices are followed.
\end{abstract}

\section{INTRODUCTION}

During 1974, imports of Irish potatoes into Puerto Rico, in various forms, amounted to $65,767 \mathrm{t}$ with a total value of $\$ 17.2$ million, including more than $\$ 2.6$ million for potato chips, dehydrated flakes and granules. "This value is higher than the total farm value of all locally produced root crops (5). When marketing at retail prices, this figure increases considerably, to over $\$ 20$ million. ${ }^{5}$ The value of the average annual imports in 1935-40 was estimated at slightly above $\$ 0.5$ million (1). Thus, a marked increase in imports has been registered throughout

${ }^{1}$ Manuscript submitted to Editorial Board October 7, 1975.

${ }^{2}$ Joint contribution from the Agricultural Experiment Station, University of Puerto Rico, Mayagüez Campus, Río Piedras, P.R. and the Department of Agronomy, Cornell University. This study was financed by Project H-94(S-9) with technical support from the staff of the Cornell-Aid Project (Research Contract csd 2490 "Soil Fertility Requirements to Attain Efficient Production of Food Crops on the Extensive, Deep, Well-Drained but Relatively Infertile Soils of the Humid Tropics."

${ }^{3}$ Associate Agronomist, Professor-Soil Scientist, and Assistant Agronomist respectively, Agricultural Experiment Station, Mayagüez Campus, University of Puerto Rico, Río Piedras, P.R.

${ }^{4}$ Pringle, G., Personal communication, December 1974.

${ }^{5}$ Pringle, G., Personal communication, January 1975. 
the years. Irish potato production has never been an extensive local enterprise, although the crop has been grown successfully in certain regions of the highlands. However, it is a staple food in the Puerto Rican diet. Irish potatoes are a good source of energy, producing $316 \mathrm{kcals}$ per pound with $2 \%$ protein and $78 \%$ water. Irish potato flour approaches the energy value of cereals (1583 kcal). Its protein content $(8.5 \%)$ compares well with that of wheat flour (10.6), corn meal (7.9), fortified rice (7.4), boiled rice (2.4), rice flour (7.2), and wheaten white bread (8.7), (3). Because of the local consumers' preference for Irish potatoes and their products, of their high economic value and of their high energy supply, it appears that the possibilities of determining the potential to produce them in Puerto Rico should be further explored. At nearby Jamaica, where similar climatic and edaphic conditions prevail, about 1,620 ha are planted to Irish potatoes. The island is self-sufficient in this item.

An Irish potato crop can be produced in less than 4 months. Thus, more than one crop can be produced per year if the cool night temperatures prove to favor tuberization and/or if varieties that tolerate warm temperatures can be obtained. Also, with the development of new varieties or clones more resistant to late blight and other diseases it appears that the potential for production of Irish potatoes merits additional studies. If they could be produced locally, imports could be reduced, more gainful employment would be available on the farm, and the balance of payments would be favorably affected. Furthermore, local factories could be established for processing and producing such items as potato chips and instant mashed potatoes. Thus, the potential for growing Irish potatoes in the Oxisols of Puerto Rico and elsewhere in the Tropics cannot be overemphasized. Furthermore, there are vast areas of these soils in tropical Latin America that if adequately managed can produce food crops abundantly and profitably.

\section{EARLIER WORK}

Preliminary research work with Irish potatoes was conducted from 1928-30, but results were contradictory. Red Bliss Triumph appeared to be the outstanding variety then. However, the highest yields were only around $13.5 t$ to the hectare (6). Rodríguez et al. evaluated different varieties for production in selected areas of Puerto Rico (8) in the 1940's. At that time, variety Kennebec performed best. With rational fertilization yields approaching $16.8 \mathrm{t} / \mathrm{ha}$ were obtained in northwestern Puerto Rico when planted early in the winter with 15 to $23 \mathrm{~cm}$ between plants in rows 61 to $76 \mathrm{~cm}$ apart. Phosphorus was the most essential fertilizer element. Early and late blight, as well as bacterial wilt, were then severe limiting factors, but now can be effectively controlled through spraying. 
Additional research work with Irish potatoes in Puerto Rico was also conducted by Landrau, Jr. et al. with fertilizers (4), Pérez-Escolar and Lugo-López (7) with synthetic soil conditioners, Cibes et al. (2) on control of premature sprouting with maleic hydrazide, and Ewing ${ }^{6}$ on screening tests for heat tolerance.

\section{MATERIALS AND METHODS}

The site of the experiment was the Isabela Substation farm in northwestern Puerto Rico on gently rolling land at about $122 \mathrm{~m}$ above mean sea level. The mean annual maximum temperature at this location is $29.4^{\circ} \mathrm{C}$, and the mean annual minimum temperature is $18.9^{\circ} \mathrm{C}$. Solar radiation ranges from an average of 300 langleys/day in the winter to 600 langleys/day in the summer. The mean annual rainfall is about $1658 \mathrm{~mm}$. The evaporation from a Class A pan is approximately $6 \mathrm{~mm}$ /day during the summer and $4 \mathrm{~mm} /$ day during the winter. The soil at the experimental site is Coto clay, a Tropeptic Haplorthox, clayey, kaolinitic, isohyperthermic. The chemical analysis from the upper $15 \mathrm{~cm}$ of the soil is as follows: $\mathrm{K}$, (available) $33 \mathrm{p} / \mathrm{m}$; P (Bray), $7.7 \mathrm{p} / \mathrm{m} ; \mathrm{P}$ (Olsen), $18.0 \mathrm{p} / \mathrm{m}$; CEC 13.3 meq; Ca, 3.17 meq; $\mathrm{Mg}, 1.83$ meq; and Al 0.6 meq. Organic matter is $4.21 \%$ and the $\mathrm{pH}$ is 5.0 .

The experiment followed a partially balanced incomplete block design with 11 treatments replicated 4 times. The treatments consisted of 8 Irish potato, varieties (Abnaki, Chieftain, Hudson, Kennebec, Norland, Sebago, Red LaSoda, Red Pontiac) and three clones (B 7165-8, B 7845-4, and B 7957-5). The clones were field resistant to late blight and were provided by the Beltsville Agricultural Research Center ${ }^{7}$.

Each plot consisted of 4 ridged rows $0.91 \mathrm{~m}$ apart and $6.10 \mathrm{~m}$ long with alleys between plots of $0.76 \mathrm{~m}$. Tubers were cut into seedpieces of approximately 57 grams. Twenty seedpieces were sown per row for a total of 80 seedpieces per plot. The experimental planting was made December 23,1974 . The plants were fertilized soon after emergence, each with 34 grams of a 10-10-10 fertilizer. Insects and diseases were controlled throughout the growing season by sprays of the fungicide Maneb $80 \mathrm{WP}^{8}$ at a rate of 1682 grams per 935 liters of water every 15 days mixed with 1121 grams of the insecticide Endosulfan (Thiodan). Disease incidence throughout the growing period was observed and recorded. When the plants became infected with disease, Benlate at the rate of $282 \mathrm{~g}$ per 935

${ }^{6}$ Ewing, Elmer E., Report on potato trials in Puerto Rico, 1973-74, Personal communication to J. Badillo-Feliciano, December 1974.

${ }^{7}$ For the purpose of this paper, the clones will be referred to hereafter as varieties.

${ }^{8}$ Trade names are used in this publication solely for the purpose of providing specific information. Mention of a trade name does not constitute a guarantee or warranty of equipment or materials by the Agricultural Experiment Station of the University of Puerto Rico or an endorsement over other equipment or materials not mentioned. 
liters of water was used every 10 days. The crop received $145 \mathrm{~mm}$ of rainfall during the growing season plus 10 rounds of supplemental irrigation. It was harvested April 10, 1975 at the age of 109 days. The tubers were classified as US No. 1 (heavier than $114 \mathrm{~g}$ ); B size (marketable tubers weighing less than 114 grams); and culls.

\section{RESULTS AND DISCUSSION}

Data on the performance of the 11 varieties are given in table 1. Marketable yields ranged from $22.4 \mathrm{t} / \mathrm{ha}$ for the Hudson variety to 14.0 t/ha for Sebago. Varieties Hudson, Red Lasoda, Red Pontiac, and Chieftain yielded more than $20 \mathrm{t} / \mathrm{ha}$ of marketable potatoes. There were no significant mean yield differences between the four above-mentioned varieties. However, the Hudson variety yielded significantly higher than Kennebec, B 7845-4, Norland, B 7165-8, Abnaki, B 7957-5, and Sebago.

Kennebec was a high yielding variety in previous trials (8) conducted in Puerto Rico. In the experiment herein reported it only yielded significantly higher as to marketable tubers than B 7957-5 and Sebago. Sebago was the lowest yielder with $14.0 \mathrm{t} / \mathrm{ha}$, i.e., $8.3 \mathrm{t} / \mathrm{ha}$ less than the yield obtained from Hudson.

Percent marketable yield ranged from a low of 90 for Norland to a high of 97 for Hudson. Varieties Chieftain, B 7845-4, Red Lasoda, Red Pontiac, and Sebago yielded above $95 \%$ of marketable tubers. Kennebec,

TABLE 1.-Performance of eleven Irish potato varieties under experimental conditions in northwestern Puerto Rico, December 1974 to April 1975

\begin{tabular}{|c|c|c|c|c|c|}
\hline Varieties & $\begin{array}{l}\text { Total } \\
\text { yield }^{1}\end{array}$ & $\begin{array}{c}\text { Marketable } \\
\text { yield }^{2}\end{array}$ & U.S. No. $1^{3}$ & $\begin{array}{c}\text { Percent } \\
\text { marketable }\end{array}$ & $\begin{array}{l}\text { Disease } \\
\text { rating }\end{array}$ \\
\hline \multicolumn{6}{|c|}{ Metric tons/ha } \\
\hline Hudson & $23.00 \mathrm{a}^{5}$ & $22.35 \mathrm{a}$ & $19.34 \mathrm{a}$ & 97 & 1 \\
\hline Red LaSoda & $22.02 \mathrm{a}$ & $20.95 \mathrm{ab}$ & $16.72 \mathrm{ab}$ & 95 & 3 \\
\hline Red Pontiac & $21.66 \mathrm{ab}$ & $20.62 \mathrm{ab}$ & $16.21 \mathrm{~b}$ & 95 & 5 \\
\hline Chieftain & $21.38 \mathrm{ab}$ & $20.45 \mathrm{abc}$ & $14.61 \mathrm{bc}$ & 96 & 4 \\
\hline Kennebec & $20.25 a b c$ & $18.89 \mathrm{bcd}$ & $14.83 \mathrm{bc}$ & 93 & 5 \\
\hline B 7845-4 & $19.54 \mathrm{bcd}$ & $18.82 \mathrm{bcd}$ & $14.11 \mathrm{bcd}$ & 96 & 3 \\
\hline Norland & $19.12 \mathrm{bcd}$ & $17.27 \mathrm{de}$ & $10.03 \mathrm{e}$ & 90 & 8 \\
\hline B $7165-8$ & 17.26 cde & 16.03 def & $11.32 \mathrm{de}$ & 93 & 10 \\
\hline Abnaki & $16.95 \mathrm{de}$ & 15.87 def & 11.94 cde & 93 & 2 \\
\hline В $7957-5$ & $16.64 \mathrm{de}$ & 15.27 ef & $8.79 \mathrm{e}$ & 92 & 10 \\
\hline Sebago & $14.80 \mathrm{e}$ & $14.03 \mathrm{f}$ & $10.71 \mathrm{e}$ & 95 & 6 \\
\hline
\end{tabular}

${ }^{1}$ Includes marketable tubers (see footnote 2) plus culls.

${ }^{2}$ Includes the U.S. No. 1 and tubers weighing less than $114 \mathrm{~g}$.

${ }^{3}$ Marketable tubers heavier than 114 grams.

${ }^{4}$ Disease rating: $8-10$, very susceptible; $6-7$, susceptible; 5 , medium susceptible; $3-4$, moderately susceptible; $1-2$, slightly susceptible.

${ }^{5}$ Yield means followed by a letter in common are not significantly different at .05. 
B 7165-8, Abnaki, and B 7957-5 yielded marketable tubers that ranged from 92 to $93 \%$ of the total tuber yields.

Hudson and Red Lasoda yielded 19.3 and 16.7 t/ha, respectively, of grade US No. 1 tubers. The mean yields of U.S. No. 1 tubers of these two varieties did not differ significantly. However, Hudson outyielded in terms of U.S. No. 1 tubers the other 9 varieties tested. Hudson, Red Lasoda, Red Pontiac, Chieftain, Kennebec and B 7845-4 yielded the larger amounts of large-sized potatoes. Sebago, Norland, and B 7957-5 yielded the least amount of U.S. No. 1 potatoes. The total yield, as expected, followed a trend similar to that for marketable yield.

The varieties differed as to their susceptibility to various diseases (table 1). Early blight, caused by Alternaria solani, and bacterial wilt, caused by Pseudomonas solanacearum, were the two most damaging diseases. There were very few cases of stem and root rot damage due to Sclerotium rolfsii. There was an apparent negative relationship between disease rating and total yield. Varieties with a low disease rating generally were the best yielders.

Varieties Hudson, Red Lasoda, Red Pontiac, Chieftain, Kennebec, and B 7845-4 were selected to be included in further variety and field management trials. There are no plans to include other varieties in further tests.

It is estimated that, at production rates of over $20 \mathrm{t} /$ ha of marketable Irish potatoes, only 3644 hectares would be required to produce the amount of this crop imported to Puerto Rico in 1974.

Further tests on the effect of time of planting, plant density, fertilizers, liming, and other soil and crop management practices are necessary prior to making definite recommendations to farmers.

\section{RESUMEN}

Se informan en este trabajo los resultados de un experimento realizado en un Oxisol (Tropeptic Haplorthox) en la zona noroeste de Puerto Rico para evaluar el potencial de producción de papas en esta clase de suelos y a bajas altitudes. Se incluyeron 11 variedades en un diseño de bloques incompletos parcialmente balanceados con 4 replicaciones. El experimento se sembró el 23 de diciembre de 1974 y se cosechó a los 109 días. Los rendimientos de papas comerciales fluctuaron de 14.0 a $22.4 \mathrm{Tm} / \mathrm{Ha}$. Las variedades Hudson, Red Lasoda, Red Pontiac y Chieftain produjeron más de $20 \mathrm{Tm} / \mathrm{Ha}$. La variedad Sebago fue la de rendimientos más bajos. El porcentaje de papas comerciales fluctuó de 90 a 97. Los rendimientos totales siguieron la misma tendencia que los rendimientos de papas comerciales. Se evidenció una aparente relación negativa entre la incidencia de enfermedades y los rendimientos totales. Se infiere de estos datos que la producción de papas ofrece posibilidades de ser una empresa viable bajo condiciones locales si se siguen prácticas adecuadas de cultivo.

\section{LITERATURE CITED}

1. Annual Book of Statistics, P. R. Department of Agriculture and Commerce, 1940.

2. Cibes, H., Samuels, G., and Rodriguez, J. P., Influence of preharvest sprays with maleic 
hydrazide on the sprouting of potatoes, J. Agr. Univ. P. R. 39(2): 92-9, 1955.

3. Gurney, J. M., Nutritional considerations regarding staples, Paper presented at the 12th. Annual Meeting, Caribbean Food Crops Society, Jamaica, July 1974.

4. Landrau, P., Jr., Rodríguez, J. P., Samuels, G., Alers Alers, S., and Gandra Caro, R., Effect of spacing and fertilization on the yields of potatoes, J. Agr. Univ. P. R. 39(2): 100-10, 1955.

5. Office of Agricultural Statistics and Economic Studies, Department of Agriculture, San Juan, P.R., July 1974.

6. Osuna, P., and Molinary-Salés, E., Hort. Insular Exp. Sta. Reports, 1928-29, 1930.

7. Pérez-Escolar, R., and Lugo-López, M. A., The effect of synthetic soil conditioners on soil-aggregate stability and the production of potatoes and stringless beans, J. Agr. Univ. P.R. 51(2): 127-33, 1957.

8. Rodriguez, J. P., and Landrau, P., Jr., Essentials of successful potato culture in Puerto Rico, J. Agr. Univ. P.R. 40(3): 157-70, 1956. 